\title{
A STUDY OF ULTRAVIOLET INDUCED LETHAL MUTATIONS IN DROSOPHILA MELANOGASTER*
}

\author{
IRWIN I. OSTER \\ Indiana University, Bloomington, Indiana
}

Received I.vi.52

THE term lethal mutation as used in connexion with the genetics of Drosophila denotes a heritable change which causes the death of the individual before maturity is reached. Since the fly undergoes a complete metamorphosis, the lethal effect can be exerted during any of the three major stages (i.e. embryo, larva, pupa) prior to the hatching of the adult fly.

Previously Medvedev (1938), in a developmental analysis of 30 cases of sex-linked lethals that had arisen spontaneously and that showed no apparent changes in their salivary gland chromosomes, found that $\mathrm{I}_{5}$ exerted their lethal effect during the pupal stage. (It is not stated to what extent the possibility of allelism among these lethals had been ruled out but they were of independent origin.) In 1939 he reported that of 12 of these same spontaneous sex-linked lethals which killed in some pre-pupal stage, 2 caused death during the embryonic period, 9 during the rst and $\mathrm{r}$ during the 2 nd larval instar. Five others among the total of 30 were observed to die in the third larval instar, at about the time of pupation. He interpreted this apparent grouping as showing three "sensitive periods"--in the embryo, the first instar, and the time of pupation, respectively. From a subsequent analysis of another group of 18 sex-linked lethals (composed of 8 spontaneous and ro ultraviolet-induced lethals which, however, were not examined cytologically) in which he found that $\mathrm{r}$ caused death during the embryonic period,

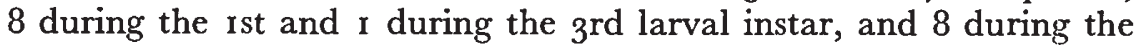
pupal period, Medvedev ( $1939 b$ ) concluded that " the inability of further development of the lethal larvae was connected with the disturbance of such processes as moulting and pupation in some of the cases, at least".

Poulson (1937, 1940, 1945) found that deficiencies usually cause embryonic death, as might be expected in view of their involving multilocus losses, since ( $\mathrm{r}$ ) the earliest effect would be the one detected and since (2) some effects would be synergistic and therefore tend, when in combination, to cause lethality at a time at which, separately, they would have been merely detrimental. Hadorn (1948) tabulated the stages of death for 38 lethals reported on in previous work of various authors. Death was found to occur at various stages and Hadorn inter-

* This investigation was supported in part by research grants from the U.S. Atomic Energy Commission and from the National Cancer Institute of the National Institutes of Health, U.S. Public Health Service. 
prets the results as showing a clustering of deaths at 4 periods: the early embryo, the period just before or after hatching from the egg case, that just before or after pupa formation, and that just before or after eclosion from the pupa case. He regards the "phases of high developmental activity" as those especially subject to the action of lethals. However, since many of the lethals used by him were known to be allelic, and many were deficiencies, the collected data which he presents are such as to provide little evidence of what the relative frequency of death at different stages would be for gene mutations.

During the past five years a large number of stocks containing lethal mutations which have occurred spontaneously or have been induced by X-rays, neutrons, or ultraviolet light have been accumulated by Dr H. J. Muller and his co-workers at Indiana University. It was desired to examine the lethals having these four origins with regard to the time during development that they kill and the morphological abnormalities that they induce. Those mutations entailing no detectable structural changes in the chromosomes, are especially well suited for throwing light on the action of individual genes on the physiological processes involved in development. Most ultraviolet lethals fall in this category. These may be referred to in a non-committal way as due to "point mutation" but the great majority are presumably results of gene mutation. This paper reports the results of a developmental study of a group of these point mutational ultraviolet-induced lethals.

\section{METHODS}

We had at our disposal a collection of sex-linked lethals which had been obtained by ultraviolet irradiation of Drosophila melanogaster spermatozoa in experiments by J. T. McQuate (I95 I). These had been localised by McQuate in linkage tests and found to show no abnormality in the frequency of crossing over. They had then been determined by Dr J. I. Valencia by cytological examination of the appropriate portion of the salivary gland chromosomes to entail no visible structural changes of the X chromosome (Valencia and McQuate, I95I).

The lethals were contained in balanced stocks, with the lethal $\mathrm{X}$ chromosome distinguished from its homologue by having the inversions (In) designated and the marker yellow body (y), and white eye (w), as well as by being normal with regard to Bar eye (B). The composition of the $\mathrm{X}$ chromosome of all these stocks was as follows, except that the locus of the lethal, $l$, could-according to the case-be anywhere in the $\mathrm{X}$ chromosome.

$$
\frac{l \mathrm{y} \mathrm{w} \operatorname{In} 49}{\mathrm{sc}^{\mathrm{s1}} \mathrm{B} \operatorname{InS}} \times \stackrel{\mathrm{sc}^{\mathrm{s} 1} \mathrm{~B} \operatorname{InS}}{{ }^{*}}
$$

The stock is balanced because females homozygous for $\mathrm{sc}^{\mathrm{si}}$ are sterile.

These stocks allow the male larvae with the lethal chromosome to be recognised by their light mouth parts (due to y) and their colourless Malpighian tubes (due to $\mathrm{w}$ ) (Bridges and Brehme, 1944). For pur- 
poses of comparison of larvae of the same age, a sample of at least 5o lethal-containing male larvae of each stock, derived from eggs laid on a given day, were transferred to a culture by themselves, and watch was kept upon them thereafter, several of them being examined microscopically each day. The preliminary findings, reported along with our interpretation, in an abstract in Drosophila Information Service (Oster, I95I), were checked by subsequent examinations. Death in embryonic stages was shown by the presence of brownish eggs and the absence of y w larvae. When death occurred in larval stages, the instar to which viability extended could be determined by the morphology of the spiracles (Rühle, I932). The moribund larvae and other stages were observed and dissected microscopically in insect Ringer's solution.

\section{OBSERVATIONS AND RESULTS OF EXPERIMENTS*}

Fifty-five of the ultraviolet-induced lethals involving " point mutations" only have been subjected to the above type of study. The numbers of lethals which become effective during the different stages of development are listed in table $\mathrm{I}$ :

TABLE I

The stages of development during which the different lethal mutations act

\begin{tabular}{|c|c|c|c|c|c|c|c|c|}
\hline \multicolumn{3}{|c|}{ Embryonic stages } & \multicolumn{3}{|c|}{ Larval instars } & \multicolumn{3}{|c|}{ Pupal stages } \\
\hline early & middle & late & ist & 2nd & 3 rd & early & middle & late \\
\hline \multirow[t]{2}{*}{ o } & o & 7 & 27 & o & 9 & 9 & o & 3 \\
\hline & & & & & & & \multicolumn{2}{|c|}{ Total 55} \\
\hline
\end{tabular}

This table indicates only the most advanced stage to which the particular lethals could survive. Since some of the deleterious effects of the mutants must have been manifested earlier in development some of the individuals must have died before the most critical stage was reached. Usually, however, there was no conspicuous dying off of the lethal larvae previous to their most critical stage.

Of these 55 stocks, 47 showed no morphological abnormalities as determined by total-mount microscopic inspection of the dead or dying stage at a $100 \times$ magnification, and dissection of them at $30 \times$, while eight exhibited some visible derangement, which might be related to the cause of death. The symbol, the designation, the locus in chromosome I, and the characteristic visible effects of these eight lethals are as follows:

ljl: lethal, jawless; 14. Dies during the ist larval instar, mouth parts poorly formed and sometimes absent.

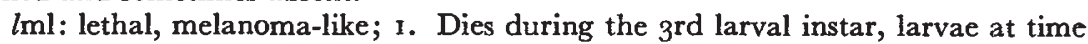
of death have internal black and brown melanotic masses (usually $x$ or 2 , sometimes as many as 10 ); may represent a malignancy.

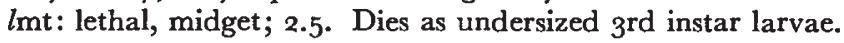

* After completion of the work reported herein it was learned through a personal communication that M. T. M. Rizki has independently carried out a similar study on another species of Drosophila and that his data (which we have not yet had an opportunity to see) are similar, so far as spontaneous lethals are concerned, to those reported here for ultraviolet. 
lrr: lethal, ring gland rudimentary; 0.3. Dies during the $3^{\text {rd larval instar, re- }}$ duction of the ring gland with associated failure to undergo the 3 rd moult, otherwise normal; often lives for $15-30$ days but does not become a giant.

lte: lethal, tracheae enlarged; 0.3. Dies during the $3^{\text {rd larval instar, main }}$ tracheal tubes greatly enlarged, sometimes lacks functional posterior spiracles.

$l$ tl : lethal, tracheae lacking; 59. Dies during the Ist larval instar, no evidence of main tracheal tubes although small side branches are present.

$l \mathrm{tr}$ : lethal, tracheae ramified; 56 . Dies during the ist larval instar, main tracheal tubes are thick and have very many side branches.

lts: lethal, tracheae stretched; 8 . Dies during the ist larval instar, very large larvae for this stage, all the tracheal tubes are very thin, suggesting that they do not grow at the same rate as the larvae and thus become stretched.

The reason why such a large proportion of the visible changes involved the tracheae is probably because these organs are so conspicuous and have such a complicated, definitely expressed morphology, alterations in which are readily observed.

\section{DISCUSSION}

A consideration of the data indicates that there is a clustering of mortality at the end of embryonic, at the beginning and end of larval life, and the beginning and end of pupal life. These are all stages where many newly developed parts and processes become functionally active for the first time. The lethal gene may have influenced development earlier but the effect on survival could have been little if any until the affected part or process was called on to participate in some vital physiological function. This is well illustrated in stock lrr. The lethal larvae of this stock remain small and live 15 days or more as 3 rd instar larvae but are unable to pupate because of a reduced ring gland. However, the ring gland deficiency already was determined during the ist and 2nd larval instars by a failure of the gland's cells to enlarge.

Although the greatest developmental changes of all take place in the early and middle embryonic period relatively few lethals were found to act then, doubtless because functioning of the new parts is not yet active and so they are not yet important for life. The successful development and functioning of the early and middle stage embryo are, to a large extent, dependent on gene products already elaborated during the previous diploid stage when the lethal mutation, being present along with its normal allele, was not exerting its deleterious effects. On the other hand, nearly half of all the lethals express themselves during the ist larval instar, when the manifold physiological (nervous, secretory, muscular, nutritive, circulatory, etc.) processes characteristic of larval life are required. Similarly, during the end of larval and the beginning of pupal life, new and different physiological processes must enter in and thus many lethals are found which express themselves then. The fact that no lethals were found which act mainly during the 2nd instar is to be expected, since that period is not characterised by radically new physiological functions but only by slight morphological changes.

In addition to the above cases of gene mutation one case of ultraviolet-induced deficiency (bands ${ }_{15} \mathrm{~A}_{2-3}$ to ${ }_{15} \mathrm{C}_{4}-5$ according to $\mathrm{J}$. I. 
Valencia) and one of translocation were studied similarly. The former proved to be lethal to the embryo, like most other deficiencies, although death occurred at a late embryonic stage. The latter caused death during the ist larval instar.

\section{SUMMARY}

I. The results are presented of a developmental analysis of 55 ultraviolet-induced sex-linked lethals due to point mutation, presumably involving in each case the alteration of an individual gene.

2. The time during development when the lethals kill and the morphological abnormalities induced by them are described. Of the eight which caused detected abnormalities, four affected the morphology of the tracheae and one gave rise to melanotic tumours.

3. There is a clustering of mortality at the end of embryonic life, at the beginning and end of larval life, and at the beginning and end of pupal life. This clustering is interpreted as being caused by the fact, not that development per se is more active at these times, but that these are the periods in which many physiological functions new to the individual come into active operation for the first time in its life.

Acknowledgment.--I wish to express my sincere apppreciation to $\mathrm{Dr} \mathrm{H}$. J. Muller for his helpful interest during the course of the work, and for his proposal of the interpretation above offered.

\section{REFERENCES}

BRidges, C. B., AND BReHME, x. S. I944. The mutants of Drosophila melanogaster. Carnegie Inst. Washington Pub. 552. Washington, D.C. 257 pp.

HADORN, E. 1948. Gene action in growth and differentiation of lethal mutants of Drosophila. Symp. Soc. Ex. Biol. Med. II, Growth, I 77-195.

MCQUATE, J. T. 195I. Some results of ultraviolet radiation of Drosophila melanogaster males. Indiana Univ. Ph.D. thesis (unpubl.).

MEDVEDEV, N. N. 1938. Studies in genetics of development. II. Influence of lethal genes on the development of characters as studied by transplantation. $C . R$. (Dokl.) Acad. Sci. U.R.S.S., N.S., 20, 319-321.

MEDVEDEV, N. N. I939a. Studies in genetics of development. III. Sensitive periods and their relation to the problem of gene action in development. C. R. (Dokl.) Acad. Sci. U.R.S.S., N.S., 22, 347-349.

MEDVEDEV, N. N. 1939b. Studies in genetics of development. IV. Further data on the sensitive periods in development of Drosophila melanogaster. C.R. (Dokl.) Acad. Sci. U.R.S.S., N.S., 25, 51 7-519.

OSTER, I. I. I95I. An analysis of ultraviolet-induced lethals due to gene mutation. Dros. Inf. Serv., 25, 124-1 26.

Poulson, D. F. 1937. Chromosomal deficiencies and the embryonic development of Drosophila melanogaster. P.N.A.S., 23, I33-1 37.

Poulson, D. F. 1940. The effects of certain X-chromosome deficiencies on the embryonic development of Drosophila melanogaster. F. Exp. Zool., 83, 271-318.

poulson, D. F. 1945. Chromosomal control of embryogenesis in Drosophila. Amer. Nat., $79,340-363$.

RÜHL, H. 1932. Das Larvale Tracheensystem von Drosophila melanogaster Meigen und seine Variabilität. Z.f. wiss. Zool., I 4I, I 59-245.

VALENCIA, J. I., AND MCQUATE, J. T. I95I. A cytogenetic analysis of 70 ultraviolet, induced X-chromosome lethals in Drosophila. (Abstr.) Rec. Genet. Soc. Amer., 20128-129; and Genetics, 36, 580-581 (1952). 